Western Washington University Western CEDAR

Fall 1999

\title{
4493 The Globalization of Women's Status: Consensus/Dissensus in the World Polity
}

\author{
Karen Bradley \\ Western Washington University, karen.bradley@wwu.edu \\ Nitza Berkovitch
}

Follow this and additional works at: https://cedar.wwu.edu/sociology_facpubs

Cart of the Sociology Commons

\section{Recommended Citation}

Bradley, Karen and Berkovitch, Nitza, "4493 The Globalization of Women's Status: Consensus/Dissensus in the World Polity" (1999). Sociology. 1 .

https://cedar.wwu.edu/sociology_facpubs/1 


\section{@SAGE}

\section{Pacific Sociological Association}

The Globalization of Women's Status: Consensus/Dissensus in the World Polity Author(s): Nitza Berkovitch and Karen Bradley

Source: Sociological Perspectives, Vol. 42, No. 3 (Autumn, 1999), pp. 481-498

Published by: University of California Press

Stable URL: http://www.jstor.org/stable/1389699

Accessed: $2 7 \longdiv { / 1 0 / 2 0 1 4 1 6 : 4 2 }$

Your use of the JSTOR archive indicates your acceptance of the Terms \& Conditions of Use, available at http://www.jstor.org/page/info/about/policies/terms.jsp

JSTOR is a not-for-profit service that helps scholars, researchers, and students discover, use, and build upon a wide range of content in a trusted digital archive. We use information technology and tools to increase productivity and facilitate new forms of scholarship. For more information about JSTOR, please contact support@ jstor.org. 


\title{
THE GLOBALIZATION OF WOMEN'S STATUS: Consensus/Dissensus in the World Polity
}

\author{
NITZA BERKOVITCH \\ Ben-Gurion University \\ KAREN BRADLEY* \\ Western Washington University
}

\begin{abstract}
The amount of attention devoted to women and women's issues has increased dramatically in the last five decades throughout the world. In this article we examine the cultural construction of women that guided such action by analyzing texts that were produced and activities that were undertaken in relation to women by international organizations from 1945 through 1995. We show that the modernist principles of universalism, liberal individualism, and rationality provided the cultural framework for this global project. We compare the ways in which two issues important to women, education and genital mutilation, were constructed by global actors and the implications of this meaning making for action over time. Our analysis reveals an important link between the extent to which an issue is constructed to be consistent with the modernist principles and the extent to which it receives global attention.
\end{abstract}

Attention devoted to women and women's issues has increased dramatically in the last five decades throughout the world. Although international efforts addressing issues presumed to be associated with women began in the nineteenth century, it was in the postwar period that such activity gained a coherent focus.

The focus of this article is the complexity embedded in the notion of "women" that motivated the network of activities, organizations, and ideas that we refer to as the global project on women's status. Our analysis of the documents and activities of the project suggests that the modernist principles of universalism, liberal individualism, and rationality guided the definition of issues and scope of strategic action. To gain greater understanding of the implications of the ideological underpinnings of the project, we compare two issues located on different points of a continuum representing legitimacy as a focus of global attention. Efforts to increase educational access for girls and women were universally supported,

* Direct all correspondence to: Karen Bradley, Department of Sociology, Western Washington University, Bellingham, WA 98225-9081; e-mail: Bradley@cc.wwu.edu. (The authors of this article are listed alphabetically and share equally in its authorship.) 
ideologically and materially. The issue of female genital mutilation, in contrast, was marked by controversy regarding its legitimacy and whether global action was appropriate. Both issues affect the lives of many women and thus would seem to be candidates for global action. Both issues were associated with an ideological and politicized tension between "tradition" and "modernity," albeit in different ways.

The analysis that we present here deepens our understanding of this particular global project and is also an important contribution to more general knowledge about the relationship between the (re)construction of issues at the global level and the impact of such meaning making on subsequent action by international organizations, activists, and governments.

\section{THEORETICAL FRAMEWORK AND RESEARCH APPROACH}

Increasingly, the context for action at the national level has become global. The policies and actions of Western European countries and the United States intending to "modernize" the "Third World" in the 1960s and 1970s are an important example of the globalization process and its multiple outcomes. Massive resources were invested, based on the conviction that all nation-states are capable of socioeconomic development providing they follow certain prescriptions to improve the state's citizens, organizations, and institutions.

The extent to which women and issues associated with women have been taken into account in such international activity has been the subject of much scholarly interest. The Women in Development literature was the forerunner, focusing on the differential impact of the global economic activities of the World Bank and multinational corporations on women and men (e.g., Boserup 1970; Gallin, Aronoff, and Ferguson 1989). Feminists have critiqued the fields of international relations and international law, arguing that international politics has depended fundamentally on men's control of women and that existing theory and research reflect this gender bias (e.g., Grant and Newland 1991). Others have questioned the role international organizations have played in promoting women's rights (Pietilä and Vickers 1990; Stienstra 1994; Winslow 1995). Recently the human rights agenda has been criticized for ignoring aspects of women's experiences of injustice (e.g., Peters and Wolper 1995).

Our research merges recent thinking about globalization processes with this body of work examining gender within international discourse. In contrast to some accounts in the literature cited above, we emphasize that women's interests do not exist a priori but rather are constructed and embedded within wider, increasingly global, cultural rules. Through activities and interactions, the meanings of "women" and "women's status" become normalized such that alternative meanings become less legitimate within the discourse. The process by which such meaning is generated and diffused is multilevel. Activities at a global level influence those on a national level, and vice versa, as we shall show.

The literature on organizational fields and loose coupling suggests a framework for understanding the relationship among the ideas, organizations, and programs that constitute the global project. Organizational fields are composed of individual and collective actors that mutually influence each other's actions and 
premises for action (DiMaggio and Powell 1983). Since the formation of the United Nations (UN), a global organizational field, or world polity, has become structurated over time with organizations, policies, and programs becoming increasingly similar in justification and structure (e.g., Barrett and Frank 1999; Thomas et al. 1987). ${ }^{1}$

Organizational fields are characterized by multiple components (organizations, ideas, activities, and persons) that are loosely or tightly coupled, or even decoupled. Ideas may be tightly coupled, such as the ideas of "progress" and "education" that justified extensive loans to less economically developed countries by the World Bank. Components may be loosely coupled, as when some organizations respond to issues without affecting other organizations or activities in the project as a whole. Understanding which components are tightly coupled and which are loosely coupled (and when) helps to explain why certain issues are responded to with a concerted, project-as-a-whole effort and why other issues are dealt with in a less focused manner.

Our theoretical framework suggests our research approach. We traced transnational discourse concerning women in texts that were produced and activities that were undertaken by international organizations and activists from 1945 through 1995. These dates coincide with the founding of the UN and its Commission on the Status of Women (the Commission) through the four UN-sponsored world conferences on women. ${ }^{2}$ We examined published and unpublished reports from international organizations, as well as the texts of international conventions, declarations, recommendations, and programs of action. Our data also include annual compendiums published by the Union of International Associations and the UN and a comprehensive data set of UN roll call votes from 1945 to 1985 (ICPSR 1987).

We first made note of the context for all references to girls and women in the various documents over time (in relation to boys or men, family, economic productivity, human rights, etc.). We reexamined the texts to determine how the issues of education and female genital mutilation were defined and addressed.

\section{THE GLOBAL PROJECT: UNIVERSALISM, LIBERAL INDIVIDUALISM, AND RATIONALITY}

The three principles of universalism, liberal individualism, and rationality are analytically distinct yet mutually reinforcing, taking focus within the global project over several decades. We briefly explain below how each contributes to understanding the overall focus of the project and consider the ways in which they are complementary.

The Commission put forth the universalist intent of the project at its founding, that is, to "raise the status of women, irrespective of their nationality, race, language or religion" (UN Yearbook 1946:530). "Universal" had a dual meaning. Activities were mobilized based on the assertion that women's status everywhere needed to be raised. In addition, universal (the same) standards would apply to all women in the world.

This notion of universality had become possible within a postwar world composed of interdependent, formally equivalent nation-states. The application of universalism in practice, however, was an early point of contestation as members 
of the UN Economic and Social Council (the Council) deliberated the extension of the UN Convention on the Political Rights of Women to those residing in territories that had not yet gained statehood. ${ }^{3}$ One UN representative expressed reservations because the "customs, traditions, and the degree of evolution of the indigenous population were such that complete equality could not be imposed at once" (UN Yearbook 1952:480). This way of thinking led to the controversial Colonial Clause (A/C.3/L.333), later overturned, that permitted states to exclude some territories from the rights embodied in the convention. Similar debate arose in discussion of the convention regarding married women's rights to nationality (A/L.218 1957). Women residing in nonstates did not have direct voice within the global project but rather had their "interests" interpreted by member states within the UN. These women were also set apart by their association with "traditional" rather than "modern" values. The classifications "traditional" and "nonstate" rendered these women marginal to the project in its early stages.

The three world conferences held during the International Decade for Women (1976-85) and the Fourth World Conference on Women in 1995 enabled the diffusion of the goals of the project by bringing together thousands of women from countries throughout the world. The universalizing intent is expressed in the Declaration of Mexico from the first conference in 1975:

Women of the entire world, whatever differences exist between them, share the painful experience of receiving or having received unequal treatment... [A]s their awareness of this phenomenon increases they will become natural allies in the struggle against any form of oppression. (UN 1975:127)

Liberal individualism provides a rationale for the universalism of the global project: all women are equivalent on the basis of their capacities to reason, in the same manner as men. Although this logic may seem self-evident today, its argument is historically specific. Before World War II, most international conventions and national legislation pertaining to women's position in society prioritized and "protected" their reproductive functions. From the 1970s onward, protective legislation increasingly was replaced with laws that treated women qua individuals, intending to equalize women's status in the public sphere with that of men (Berkovitch 1999a). Simultaneously, the Women in Development movement invoked a vision of women as human capital resources by demanding recognition of women's contributions to socioeconomic development and their integration into development planning (Sen and Grown 1987; Tinker 1990).

The ideals of universalism and liberal individualism were strategically linked to raising women's status through the rationalization of the project. Means/ends relationships were specified and formalized into bureaucratic procedures and structures. As the goal of improving women's status became identified as gender parity, measurement of progress was possible. Data were collected and reports written that compared men's and women's share of education, employment, and political participation (UN 1985b, 1995; UNESCO 1994). The status of women within nation-states became a measure of the modernity of nation-states themselves. Nation-state progress and progress on women became tightly coupled (Fraser 1987; Johnson 1994). 
As more issues were identified as integral to the advancement of women, the organizational infrastructure of the project expanded dramatically. The Decade for Women saw more women's international organizations founded than in any previous decade (Berkovitch 1999b). Also an increasing proportion of UNESCO's funds directed toward "women's programs" were devoted to research and interorganizational coordination (UNESCO 1995b).

The Convention on the Elimination of All Forms of Discrimination against Women (CEDAW), adopted in 1979, epitomizes the rationalization of women's status. The convention consists of thirty articles, intended to be an "international bill of rights for women" (Boutros-Ghali 1996:1). Objectives were linked with strategies, justified by the logic of liberal individualism. Reiterated throughout CEDAW is the bench-line marker "on the basis of equality of men and women." CEDAW also took the unusual step of authorizing the establishment of a monitoring board to oversee nation-state progress in meeting project objectives.

On the one hand, the programs and policies associated with the global project on women's status set universal standards for the promotion of women's rights everywhere. On the other hand, these same procedures exposed and maintained conflict between opposing visions of women's roles in society. CEDAW came into force with less delay than any previous human rights convention, ratified by an unprecedented 134 countries. It also has the largest number of reservations-51 ratifying countries entered 127 reservations (UN 1996). Issues associated with the family, such as inheritance, divorce rights, parental rights, and children's nationality, drew the most opposition. Eight Islamic countries ratified while affirming that Shariah law, based on the Qur'an, superseded CEDAW's provisions for gender equality. Several Arab countries still have not ratified CEDAW, including Iran, Lebanon, Oman, Qatar, Saudi Arabia, and the United Arab Emirates (UNDP 1997).

As the project expanded, it sometimes conflicted with the politics of the cold war, the unequal distribution of power and resources among the "northern" and "southern" member states of the UN, and religious ideologies. Debates over the 1980 and 1985 World Conference programs reflected lines of division within the UN as a whole and were endorsed only after considerable negotiation (Winslow 1995). Issues concerning reproduction and sexuality were met with opposition from organized alliances among Islamic and Catholic groups at these conferences as well as at the 1994 International Conference on Population and Development (ICPD) (Dixon-Mueller 1993; Johnson 1994). ${ }^{4}$

In sum, the goals and strategies of the global project to elevate the status of women were based on the principles of universalism, liberal individualism, and rationality. Within this overarching framework, however, certain topics and certain groups presented challenges to the notions of universalism and liberal individualism. The roles and rights of women within the context of the traditional family unit and reproduction remained controversial as conflict emerged between secular and religious ideologies. We now consider two issues, education and genital mutilation, that early entered as candidates for attention within the global field but were handled very differently within the global project. By examining focal points of consensus and of conflict, we gain additional insight into the dynamic relationship between ideas and action organized at the global level. 


\section{THE EDUCATION OF WOMEN AND GIRLS: CONSENSUS IN THE GLOBAL PROJECT}

Increased access to education for women and girls was consistently both a strategy and a goal of the project on women's status. Whereas in previous decades education was considered an elite privilege, the idea that people from all walks of life should have access to education became widely accepted during the postwar era. International organizations and governments endorsed educational expansion based on two complementary beliefs. Human capital assertions that an educated citizenry would lead to increased economic productivity for the nation as a whole prompted the World Bank to loan governments in less economically developed countries funds to expand educational infrastructures. Governments thus were provided an instrumental motivation to increase the level of overall educational attainment (Murphy 1995). In addition, education was designated as a human right within the emerging global human rights discourse (Ramirez and Boli 1987; UNESCO 1995a). The UNESCO Convention Against Discrimination in Education (1960) and General Assembly resolutions endorsing educational expansion were passed with no opposition (ICPSR 1987; McNeely 1995).

Within this context of support for increased educational access, the education of women and girls was an early priority of international organizations. The Council and the Commission unanimously adopted resolutions and initiated activities regarding women's education almost every year since 1946. In contrast to disagreement about the extension of other rights to persons in nonstate territories, the General Assembly overwhelmingly passed resolutions in 1949 (Resolutions B, C, and D, A/923, Annex II), 1952 (A/C.4/L.173), and 1957 (A/C.4/L.459) endorsing their right to education.

Although there was no debate concerning whether to educate women and girls, the rationale for education shifted over time, echoing the way in which women were conceptualized within the global field. During the 1950s, women's education was endorsed almost exclusively by emphasizing the benefits of educated mothers (UN Yearbook 1956; see also Labarca et al. 1953). Reflecting the emphasis on women as human capital resources that emerged with the Women in Development movement, however, educating women was linked to socioeconomic progress within the program of the Second UN Development Decade (1970-80). The new argument to educate women emphasized women's new multifaceted identities, summarized in the official document of the world conference on women in 1985:

Governments should strengthen the participation of women at all levels of national educational policy and in formulating and implementing plans, programmes, and projects. Existing and new services should be directed to women as intellectuals, policy-makers, decision-makers, planners, contributors and beneficiaries. (UN 1985b, par.163)

Although the World Bank was slow to implement most programs aimed at improving women's status, the education of girls and women received early and consistent attention. Funds designated for this purpose peaked during 1979-81, following the publication of a World Bank document linking the education of girls 
with lower fertility, creating another instrumental link between education of girls and women and progress (Murphy 1995).

The organizational infrastructure of the world polity enabled the diffusion of policies and practices aimed at removing barriers to schooling throughout the world. Information, experts, and technology were sent by UNESCO and the World Bank to establish schools and training centers in less economically developed countries. Efforts to increase the participation of women and girls in education were carried out in an increasingly rationalized manner: curriculum was specified; schools were constructed according to centralized planning; students were counted; and textbooks were cleansed of sexist language. Although both formal and informal education were encouraged, access to schools remained a World Bank priority (Stromquist 1994).

Education for women was prioritized by women's international nongovernmental organizations (INGOs) as well. From 1945 through 1995, approximately 40 percent of all women's international organizations included education either in their missions or in their activities (Union of International Associations 1945-98). Education became linked to the empowerment of girls and women more generally with the expectation that education would increase control by women "over themselves and their destiny" (UNESCO 1995a:9).

The principle of liberal individualism legitimated gender parity in education: "It was essential to have identity of basic programmes if all children were to have an equal chance of really benefiting from educational opportunities" (UN Yearbook 1953:430). The goal of equalizing all aspects of education met with some resistance in several countries, however. In response, UNESCO, UNICEF, and the World Bank implemented programs intended to supplant opposition based on "traditional cultural values" with attitudes conducive to expanding educational access (Kardam 1991; UNESCO 1975, 1992).

The modernization framework coupling education and progress legitimated such efforts. Education was not recognized as a cultural product, despite the clearly normative content of the curriculum and its intended goal of constructing a social order based on a set of beliefs normalized in the global discourse (Staudt 1998). "Culture" referred to the set of beliefs invoked by parents to prevent their daughters from being educated. International organizations did not need to defend their actions to change the attitudes of persons opposing the education of girls and women because these beliefs were widely viewed as impediments to progress. The UN Secretary-General of the International Women's Year made this point explicit when she spoke of the intent "to raise international consciousness of the need to promote equality and change traditional attitudes" that might interfere with project goals (Sipila 1975:1).

Consistent with the liberal individualist approach, coeducation was endorsed as the most optimal strategy to assure equality of opportunities (e.g., Article 10 of CEDAW). Some cultural traditions did not oppose the educational access of girls and women per se but opposed full coeducation at every level. In this instance, separate but equal facilities for males and females were considered a reasonable compromise (UNESCO 1993, 1995b; UNESCO/UNICEF 1983). If parents were unwilling to send their daughters long distances to school or to have their daughters 
taught by men, more schools should be built and more female teachers trained. This encourages access while not challenging the cultural beliefs underlying this differential treatment of sons and daughters (Bemmelen and van Vliet 1985; Stromquist 1994). This organizational approach also does not consider whether girls and boys experience the same classroom in the same way (Staudt 1998). Although coeducation was promoted officially, actual practice was loosely coupled to allow for particularistic accommodation. A committee of experts evaluating the Medium Term Plan of the International Decade asserted that the "practical meaning" of "equality for men and women . . . meant equality of opportunity" (UNESCO 1986:3).

The discourse of the campaign to educate women and girls consistently echoes that of the global project to elevate the status of women. It was intended to apply to all women everywhere, to raise all aspects of educational attainment to gender parity, and to upgrade women's skills to enable their contribution to national development in measurable ways. The strategies to accomplish these goals were described in plans that were initiated, funded, and implemented by a wide range of international organizations. Counteracting "traditional opposition" to the educational access of girls and women was considered necessary to enhance women's status and to promote socioeconomic development. In contrast, discourse concerning female genital mutilation is characterized by conflicting definitions of the issue and inconsistency concerning how it should be addressed.

\section{GENITAL MUTILATION: CONFLICT IN THE GLOBAL PROJECT}

The phrase "female genital mutilation" refers to a group of practices including circumcision, excision, and infibulation of female genitalia experienced by approximately 100 million women. These practices are found among certain ethnic groups rather than nationalities, inside twenty-eight countries located within the middle of Africa and crossing over the Red Sea to Yemen and Oman. ${ }^{5}$ The practices have diffused to Europe, Australia, and North and South America via immigrant populations (Hosken 1993; WHO 1996).

When asked by researchers, the reason most frequently cited by both men and women for continuance of genital mutilation is "tradition" (Carr 1997; El Dareer 1982; El Saadawi 1980; UN 1986). ${ }^{6}$ Genital mutilation has been a female initiation rite in some societies; in other societies, the procedures are performed on infants. It has been widely documented that genital mutilation is intended to control female sexuality by reducing the genital sensitivity of women. Intercourse becomes painful and dangerous, neither the intent nor the consequence of male circumcision (El Dareer 1982; Lightfoot-Klein 1989; Toubia 1993).

Female genital mutilation is an integral part of the gender-differentiated status system of the societies in which it is practiced. Women who are not circumcised have had little chance of marriage within these communities. These women are viewed as "unclean," and their virginity, necessary for marriage, is put in question. Since women in these societies are often not allowed to own property or otherwise earn a living, exclusion from marriage places these women in serious jeopardy.

The first efforts to address female genital mutilation within the global project 
were made in the 1950s with much hesitation and little success. In 1952 the Council asked the Trusteeship Council and administrative states to take immediate action to abolish in the territories all customs that "violate the physical integrity of women" (Resolution 445C [XIV]). It was noted, however, that any action should be done "progressively" since these practices were associated with "religious customs that had been firmly established for centuries" (E/L.334). Following debate, the final resolution (445C [XIV]) adopted by the Trusteeship Council endorsed immediate action.

A period of inattention followed until 1958 when the Council requested the World Health Organization (WHO) to undertake a study of the persistence of and measures planned to stop "ritual practices affecting the physical integrity of young girls in some areas of the world" (Resolution $680 \mathrm{BII}$ [XXVI]). WHO did not comply, declaring in 1959 that such a study was outside of its competence as these "practices were of a social and cultural rather than medical nature" (UN Yearbook 1959:205). The United Nations International Children's Fund (UNICEF) also declined to get involved. The Council's subsequent requests for government action and for the study were also denied (Resolution 771D [XXX]; Resolution 821 II [XXXII]). The First World Conference on Women in 1975 passed without any reference to the issue. In 1979, at a WHO-sponsored seminar, the practices were condemned as a health hazard, and governments were called on to adopt policies for their abolition. With the labeling of genital mutilation as a health hazard, UNICEF overcame its initial reluctance and began collaborating with $\mathrm{WHO}$ to promote its eradication.

A regional conference held in 1979 on women and development condemned the practices, while being critical of "uninformed" international campaigns, and called on governments and women's organizations to seek solutions to the problem (Dorkenoo 1995:61). This statement sets the tone for the decade: genital mutilation was to be most effectively addressed locally rather than by way of a global field approach. Uncertainty remained as to the legitimacy of the issue within the global project as a whole.

The practices were not discussed at all in the main policy document of the 1980 UN-sponsored World Conference on Women. Simultaneous with the 1980 conference, and typical for such global meetings, a forum of international nongovernmental organizations (NGOs) also met, involving eight thousand women from countries throughout the world. Here, in contrast to the official conference, the discussion of genital mutilation invoked a heated debate and received considerable Western media attention. Some feminists from Europe and the United States had begun publicly criticizing the practices and the lack of action by international organizations (Brennan 1989:nn. 47-48; Hosken 1993). Through their persistence, female genital mutilation was reintroduced as an issue to be addressed within the global field.

Conflict concerning who had the right to re-present the issue within the global arena again revealed "First World/Third World" tensions among women. Straightforward condemnation of the practice by Western/First World women was defined by some as being insensitive to the real needs and priorities of women in less economically developed countries (ISIS 1987:12). The president of the Association of African Women for Research and Development passionately declared, 
The aggressive nature of the campaign, the insensitive attitude toward a different culture, the paternalism and activism displayed have left us shocked and enraged. ... In their desire to stir the passions of the general public in the West, the men and women responsible have forgotten that they might be damaging the self-respect of the very women they are setting out to "save," by destroying the foundations of their beliefs (Savane 1978:38; also see discussions in Brennan 1989; Gunning 1992).

Savané (1978:39) further stated that "feminists from developed countries" must accept that genital mutilation is a problem for African women who themselves must speak out in favor of the eradication of the practices. The universalist assumption of the 1975 Declaration of Mexico that women throughout the world would become "natural allies in the struggle against any form of oppression" was directly challenged. The issue of female genital mutilation was being reclaimed by women who did not want to be viewed and judged "through Western eyes" (Mohanty 1991). Genital mutilation became an expression of resistance to the imposition of "Western values" that were exported with modernization. Some members of so-called traditional societies objected to the imposition of different cultural rules celebrating the rights of the individual, removed from the ethnic or familial unit. The very fabric of their society was threatened, and such attempts met with an impassioned response.

Still resisting the way Western women seemingly took control of the issue, many African women from countries in which genital mutilation was prevalent condemned the practices and organized for their eradication (Giorgis 1981; Hosken 1993; Toubia 1993). In 1984 participants from these countries endorsed eradication at the Traditional Practices Affecting the Health of Women and Children conference in Dakar. This meeting led to the formation of the Inter-African Committee on Traditional Practices Affecting the Health of Women and Children (IAC), with national committees in twenty-six African and four European countries and collaborative projects with numerous international organizations. Women also mobilized to eradicate genital mutilation in Somalia via the Congress of Somali Democratic Women's Organization, in Ethiopia via the African Training and Research Center, and in Kenya via the National Council of Women, as well as elsewhere (Dorkenoo 1995; Hosken 1993; McLean and Graham 1985).

In 1981 a human rights organization submitted a report about the consequences of genital mutilation to the UN Sub-Commission on Prevention of Discrimination and Protection of Minorities. It asserted that the practices were health-threatening and a violation of human rights. The Sub-Commission debated for two years as to whether it should study the issue and whether human rights was the appropriate framework to use. Finally, the Sub-Commission designated a working group to conduct a study on "traditional practices affecting the health of women and children" (Commission on Human Rights Resolution 1984/48). The group approached the subject of "female circumcision" with "sensitivity" and "respect"(Brennan 1989). Western members took the concerns of their African counterparts seriously "by largely holding their silence throughout the debate" (Brennan 1989:383). In 1986 this UN-sponsored study concluded that genital mutilation should be stopped (C/CN.4/1986/42). 
Twenty-eight years previously, when genital mutilation was conceptualized as a purely cultural issue, WHO had declared it outside of its mandate. In a dramatic reversal WHO and other international organizations declared in the 1980s that genital mutilation was a significant medical issue for women. In response, the procedures have been increasingly performed by trained medical personnel in clinical settings (Carr 1997; Dorkenoo 1995; Hosken 1993). WHO formally opposed such "medicalization" of the practices, as have other international organizations and some governments (WHO 1996). The question that was brought into the open was whether genital mutilation would remain an issue if the health hazards were removed. It was necessary for those advocating eradication of genital mutilation to justify their opposition on other grounds.

A major turning point in the incorporation of genital mutilation into the global project on women was its recognition as a violation of human rights. The human rights discourse takes a universalist stance: the same set of standards should protect all members of any society. Only violations of citizen rights by agents of the state had been considered legitimate within this framework. Much of the violence against women (dowry death, battery, rape), however, is done by private individuals, often by the women's own relatives (Bunch and Fried 1996). Activists mobilized throughout the 1980s and 1990s to incorporate harms done to women because of their gender into existing laws and to define "women's rights" as "human rights." As the human rights agenda expanded to include harms done to women by nonstate parties, the human rights project and the project on women's status overlapped.

Amnesty International recognized female genital mutilation as a human rights violation in 1995 (Amnesty International 1998). The right to health, the right to physical and sexual integrity, and the rights of the child have been found to be violated by the practices of genital mutilation, as put forth in the Universal Declaration of Human Rights (1948), the African (Banjul) Charter on Human and People's Rights (1981), the Declaration of the Rights of the Child (1959), and CEDAW (1979) (Dorkenoo 1995; Smith 1992; WHO 1996). Genital mutilation endured for centuries before its categorization as a health hazard and a violation of rights. Likewise, international conventions and statements of human rights long existed with provisions that could have been applied to these practices. The link between genital mutilation and global action was enabled by the redefinition of the practices and of the notion of human rights within the world polity.

In the 1990s the struggle to fight female genital mutilation was entwined with a rapidly growing campaign confronting violence against women. The UN Declaration on the Elimination of Violence Against Women (A/Res/48/104, 1993) declared that female genital mutilation is a form of such violence (Article 2). Furthermore, "states should not invoke any custom, tradition or religious consideration to avoid their obligations with respect to its elimination" (Article 4) and should adopt all appropriate measures to modify social and cultural patterns of conduct (Section J). This statement is significant in two ways. First, it labeled as illegitimate such statements as the 1959 declaration by WHO that invoked "culture" as a justification for noninvolvement in efforts to eradicate female genital mutilation. Second, the language echoes that used to endorse campaigns promoting educational 
access by legitimating confrontation of cultural opposition. In the 1995 World Conference on Women genital mutilation was identified as an act of violence, accompanied by resolutions advocating education and governmental legislation (\#38 in Global Framework; \#277d and \#283 in Platform for Action 1995).

This reframing of female genital mutilation has enabled the various parties in the project on women's status to speak in a more consistent voice about its negative consequences. IAC has been in the forefront of "africanizing solutions for sensitive problems related to culture and tradition," "combating traditional practices that are harmful to the health of women and children," and protecting and improving "practices that are found to be beneficial" (UN 1987). This is a clear strategy to remove the negative connotation of "tradition" as an obstacle to "progress" in global discourse.

The issue of genital mutilation is also being recast in such a way as to make it consistent with the underlying principles of the project on women's status and thereby to legitimate more concerted efforts. There have been attempts to move genital mutilation from being considered a "private" practice by connecting its eradication to achievement of higher collective goals: "With growing pressure on countries to increase productivity, it is imperative that the huge waste of human resources caused by deliberate injury and other actions that limit women's full participation in the development of their homelands should be stopped" (KosoThomas 1995:135).

Female genital mutilation has been identified by the Commission (E/CN.6/ 1995/3/Add.2) and by UNESCO as an obstacle to the education of girls and thus to national progress (UNESCO 1993, 1995a). The assertion that the practices interfere with the rights of girls and women to develop their human capital in a manner equivalent to boys and men renders the issue compatible with the liberal individualist framework. Arguments have also been made to present female genital mutilation as one instance of the universal institution of patriarchy, thereby eliminating its particularistic association.

We must see FGM [female genital mutilation] as part of the global subordination of women. None of the underlying messages and language used to justify FGM is unique to Africa. These messages reflect a universal language used to perpetuate women's second-class status and are reminiscent of reasons given for slavery, colonialism, and racism. (Toubia 1995:232)

Thus the discourse surrounding female genital mutilation has shifted to be more consonant with the principles of universalism and liberal individualism. With this reframing of the issue, rationalization is slowly emerging. WHO adopted "female genital mutilation" as the official term to refer to a set of practices now identified in an official typology within its "Genital Mutilation Information Kit" (WHO 1996). Unlike the extensive data collected on educational enrollment, however, there is currently no reliable country-by-country data base on the prevalence of genital mutilation. ${ }^{7}$ WHO, UNESCO, and various NGOs have declared that education programs implemented at the local level are the optimal strategy to promote eradication. Some interorganizational cooperation has begun, although fewer NGOs have been formed specifically to eradicate female genital mutilation 
compared to those addressing the education of girls and women. Few governments have established agencies dedicated to eradicating the practices, and few national laws have been passed (Hosken 1993; WHO 1996).

\section{CONCLUDING REMARKS: THE RELATIONSHIP BETWEEN MEANING AND ACTION}

In the early years of the global project on women's status, female genital mutilation and education were located on opposite ends of a continuum representing legitimacy as a global issue. As cultural meanings changed in the global discourse, so did the legitimacy of these issues. In particular, changes in the meanings of women, human rights, and culture have been significant in both the definition of the issues and subsequent strategies for action.

Although education remained a priority throughout our study, the justification for schooling shifted as the cultural construction of women was modified over time. Efforts to increase educational opportunities by governments and international organizations emanated from the belief that schooling would lead to socioeconomic progress. As these parties recognized women as human capital resources, their education became constructed as more relevant for progress. This framing of the issue does not recognize education as a culturally constructed status-granting institution. Culture was identified with the traditions that blocked access of girls and women to formal schooling. Thus it was considered necessary and unproblematic to overcome such traditional opposition.

Female genital mutilation consistently has been associated with both culture and tradition within the discursive frame of the global field, although the political implications of this association have varied over time. Activists, scholars, and bureaucrats have debated whether genital mutilation violates human rights regardless of cultural justification, or whether condemnation of these practices takes into account their cultural significance (Brennan 1989; Hosken 1993; Kopelman 1994). With the declaration of tradition to be an illegitimate justification for the perpetuation of the practices, more concerted global action followed. In contrast to the uncontested institutionalization of educational credentials as the basis for social differentiation, concern arose that sudden eradication of female genital mutilation would create a "cultural vacuum." In response, suggestions have been made for alternative ceremonial acts to mark the transformation of "girls" into "women" (Dorkenoo 1995; Hosken 1993; WHO 1996).

The differential treatment of the issues of educational access and female genital mutilation within the global field reveal that the principles of universalism and liberal individualism are tightly coupled to the recognition of project foci. This recognition triggers transnational cooperation, multiple modes of action, and rationalization. The education of girls and women is an exemplar of this scenario.

If an issue is defined to have some inconsistency vis-à-vis the framing principles of the project, it may be decoupled or loosely coupled. Female genital mutilation was decoupled from the global field when WHO claimed in 1959 that the cultural foundation of the practices placed the issue outside of its mission. Genital mutilation was loosely coupled as activists rather than international organiza- 
tions engaged in local/regional activity. During the 1980s, genital mutilation was recognized as a health hazard by $\mathrm{WHO}$ and by local leaders who had legitimacy within the countries where the practices are mostly concentrated. This enabled some limited and tenuous global action. During the 1990s, human rights violations were redefined to include violent acts performed by private actors. Female genital mutilation was defined in such a way as to be consistent with the project focus: a violent act, an obstacle of progress, and another form of more general oppression of women, conceptually universal, if not literally so.

The conflict surrounding the appropriate response to female genital mutilation also reveals the highly political implications of the construction of "women" as a category of social attention. Female genital mutilation is clearly linked to both sexuality and reproduction-issues aligned with the cultural construction of women throughout time. In some societies uncircumcised women are viewed as sexually unappealing to men. Politically, the role of women as mothers has significance for the perpetuation of family lines, ethnicities, nationalities, and expansionist religions. Thus it should not be surprising that issues associated with reproduction and sexuality, such as female genital mutilation, are lightning rods for conflict (McDaniel 1996).

Debates in international forums over women's right to abortion and women's rights within family law have revealed alternative visions to a universal, liberalindividual woman. The cultural meaning ascribed to "women" in these challenges emerges from an embodied conceptualization of women as mothers and women as sexual beings. With the redefinition of female genital mutilation as both an act of violence and a health hazard, female genital mutilation was decoupled from these contested issues surrounding women and more tightly coupled to the principles of the global project.

Issues are constantly available for attention. We propose, based on this case study of the project on women's status, that global field action is most likely to emanate from meaning that is generated to be consistent with the central principles of modernity. Issues that are constructed to be consequential for progress, and couched in the language of universalism, liberal individualism, and human rights, are more likely to become rationalized and amenable to global action. Alternatively, when issues are not constructed in a manner consistent with these central tenets, local action is more likely to result, decoupled or loosely coupled from global field action. This action may be consequential locally but will not command concerted global attention until either the issue is redefined to be consistent with the aforementioned principles or the central tenets of the global field are redefined to accommodate the issue.

The project on women's status has withstood multiple challenges from within and outside its amorphous boundaries concerning how to define women, how to measure progress, and who should re-present women's interests. Questions about the effectiveness of these activities and whether the efforts are sufficient for the magnitude of the problem abound (see, e.g., Staudt 1998). Similarly, debates concerning the best measures of women's status continue to swirl (Bradley and Khor 1993; Young, Fort, and Danner 1994).

In our study we have focused attention on the context in which these debates 
unfold, highlighting the importance of the relationship between ideas constituted at the global level and action at global and local levels. This research has revealed that the process of globalization involves contested and negotiated meaning. Understanding the intensity of the debates surrounding the meaning of "women" and "women's status" necessitates an understanding of the implications of meaning for action.

Acknowledgments: An earlier version of this article was presented at the Annual Meeting of the American Sociological Association, August 1994, Los Angeles. Our paper benefited from the comments of John W. Meyer, Francisco O. Ramirez, John Boli, Deborah Barrett, and Manuel Eisner, as well as those of anonymous reviewers. This research was assisted by a grant to Karen Bradley by the Bureau of Faculty Research at Western Washington University and was conducted, in part, while she was a Visiting Scholar at the Federal Institute of Technology, Zurich, Switzerland. The authors are grateful to Lydia Ruprecht and the documentation specialists at UNESCO headquarters in Paris and at WHO headquarters in Geneva for their assistance in obtaining relevant documents.

\section{NOTES}

1. We use "world polity" and "global field" interchangeably.

2. The dates are 1975, in Mexico City; 1980, in Copenhagen; 1985, in Nairobi; and 1995, in Beijing.

3. Seventy-four Non-Self-Governing Territories existed from 1946 through 1960. By 1994 all had either gained independence or joined with an independent state.

4. Bangladesh, Saudi Arabia, Sudan, and Turkey boycotted ICPD, declaring the Programme of Action to be in conflict with Islamic law (Johnson 1994).

5. The twenty-eight countries identified by WHO (1996) are Benin, Burkina Faso, Cameroon, Central African Republic, Chad, Côte d'Ivoire, Djibouti, Egypt, Eritrea, Ethiopia, Gambia, Ghana, Guinea, Guinea-Bissau, Kenya, Liberia, Mali, Mauritania, Niger, Nigeria, Senegal, Sierra Leone, Somalia, Sudan, Togo, Uganda, United Republic of Tanzania, and Zaire.

6. Other reasons included religion, health, fertility, and sexual pleasure for men.

7. Carr (1997) reports survey data from six African countries. WHO (1996) and Seager (1997) base their estimates on Hosken's (1993) estimates. Hosken extrapolated from the extent to which various ethnic groups practice genital mutilation to compute country estimates.

\section{REFERENCES}

Amnesty International. 1998. Female Genital Mutilation-A Human Rights Information Packet. http://www.amnesty.org/ailib/intcam/femgen/fgm2.htm.

Barrett, Deborah A. and David Frank. 1999. "Population Control for National Development: From World Discourse to National Policies." Pp. 198-221 in Constructing World Culture, edited by J. Boli and G. M. Thomas. Stanford: Stanford University Press.

Bemmelen, Sita van and Maaike van Vliet. 1985. Coeducation versus Single-Sex-Schooling: A 
Comparison between Western and Third World Perspectives. The Hague: Centre for the Study of Education in Developing Countries.

Berkovitch, Nitza. 1999a. From Motherhood to Citizenship: Women's Rights and International Organizations. Baltimore: Johns Hopkins University Press.

- 1999b. "The Emergence and Transformation of the International Women's Movement." Pp. 100-26 in Constructing World Culture, edited by J. Boli and G. M. Thomas. Stanford, CA: Stanford University Press.

Boserup, Ester. 1970. Women's Role in Economic Development. New York: St. Martin's Press.

Boutros-Ghali, Boutros. 1996. "Overview." The United Nations and the Advancement of Women, 1945-1996. New York: UN.

Bradley, Karen and Diana Khor. 1993. "Toward an Integration of Theory and Research on the Status of Women." Gender and Society 7(3):347-78.

Brennan, Kathleen. 1989. "The Influence of Cultural Relativism on International Human Rights Law: Female Circumcision as a Case Study." Law and Inequality 7:367-98.

Bunch, Charlotte and Susan Fried. 1996. "Beijing 95: Moving Women's Human Rights from Margin to Center." Signs 22(1):200-204.

Carr, Dana. 1997. Female Genital Cutting. Baltimore, MD: Demographic and Health Surveys Program.

DiMaggio, Paul J. and Walter W. Powell. 1983. "The Iron Cage Revisited: Institutional Isomorphism and Collective Rationality in Organizational Fields." American Sociological Review 48(April):147-60.

Dixon-Mueller, Ruth. 1993. Population Policy and Women's Rights: Transforming Reproductive Choice. Westport, CT: Praeger.

Dorkenoo, Efua. 1995. Cutting the Rose. London: Minority Rights Group.

El Dareer, Asma. 1982. Woman, Why Do You Weep? London: Zed Press.

El Saadawi, Nawal. 1980. The Hidden Face of Eve. London: Zed Press.

Fraser, Arvonne S. 1987. The U.N. Decade for Women. Boulder, CO: Westview Press.

Gallin, Rita S., Marilyn Aronoff, and Anne Ferguson. 1989. "Women and International Development: Creating an Agenda." Women and International Development Annual 1:1-22. Boulder, CO: Westview Press.

Giorgis, Belkis Wolde. 1981. "Female Circumcision in Africa." ST/ECAATRCW/81/02. Addis Ababa: UN.

Grant, Rebecca and Kathleen Newland, eds. 1991. Gender and International Relations. Bloomington: Indiana University Press.

Gunning, Isabelle R. 1992. "Arrogant Perception, World-Traveling and Multicultural Feminism: The Case of Female Genital Surgeries." Columbia Human Rights Law Review 23:189-248.

Hosken, Fran. 1993. The Hosken Report. Lexington, MA: WIN NEWS.

IAC (Inter-African Committee on Traditional Practices Affecting the Health of Women and Children). 1997. Newsletter no. 22, December.

ICPSR. 1987. UN Roll Call Data. Ann Arbor, MI: Inter-University Consortium for Political Research.

ISIS: An International Feminist News Magazine. 1987. "Circumcision and Muslim Law: Not the Only Two Issues for Egyptian Women." 14:11-12.

Johnson, Stanley. 1994. The Politics of Population: Cairo 1994. London: Earthscan Publications.

Kardam, Nuket. 1991. Bringing Women In. Boulder, CO: Lynne Rienner Publishers.

Kopelman, Loretta M. 1994. "Female Circumcision/Genital Mutilation and Ethical Relativism." Second Opinion 20, no. 2(October):55-71.

Koso-Thomas, Olayinka. 1995. "Tradition against Health: The Struggle for Change." Pp. 
122-35 in The Diplomacy of the Oppressed: New Directions in International Feminism, edited by G. Ashworth. London: Zed Books.

Labarca, H. Amanda, K. L. Joshi, P. D. Shukla, Mitra Mitorvich, and Vida Tomsich. 1953. Women and Education. Paris: UNESCO Press.

Lightfoot-Klein, Hanny. 1989. Prisoners of Ritual. New York: Harrington Park Press.

$\rightarrow$ McDaniel, Susan A. 1996. "Toward a Synthesis of Feminist and Demographic Perspectives on Fertility." Sociological Quarterly 37(1):83-104.

McLean, Scilla and Stella Efua Graham, eds. 1985. "Female Circumcision, Excision, and Infibulation." Minority Rights Group. Report no. 47.

McNeely, Connie. 1995. "Prescribing National Educational Policies: The Role of International Organizations." Comparative Education Review 39(4):483-507.

Mohanty, Chandra Talpade. 1991. "Under Western Eyes: Feminist Scholarship and Colonial Discourses." Pp. 51-80 in Third World Women and the Politics of Feminism, edited by C. T. Mohanty, A. Russo, and L. Torres. Bloomington: Indiana University Press.

Murphy, Josette L. 1995. Gender Issues in World Bank Lending. Washington, DC: World Bank.

Peters, Julie and Andrea Wolper, eds. 1995. Women's Rights, Human Rights: International Feminist Perspectives. London: Routledge.

Peterson, V. Spike, ed. 1992. Gendered States: Feminist (Re)Visions of International Relations Theory. Boulder, CO: Lynne Rienner Publishers.

Pietilä, Hilkka and Jeanne Vickers. 1990. Making Women Matter: The Role of the United Nations. London: Zed Books.

Ramirez, Francisco O. and John Boli. 1987. “Global Patterns of Educational Institutionalization." In Institutional Structure, edited by G. M. Thomas, J. W. Meyer, F. O. Ramirez, and J. Boli. Newbury Park, CA: Sage.

Savané, Marie-Angélique. 1978. "Why We Are against the International Campaign." International Child Welfare Review 40:38-39.

Seager, Joni. 1997. The Status of Women in the World Atlas. London: Penguin.

Sen, Gita and Caren Grown. 1987. Development, Crises, and Alternative Visions. New York: Monthly Review Press.

Sipila, Helvi. 1975. "Half of Humanity." World Health (January):1. Geneva: WHO.

Smith, Robyn Cenry. 1992. "Female Genital Mutilation: Bringing Women's Perspectives into the International Debate." Southern California Law Review 65(July):2449-2504.

Staudt, Kathleen. 1998. Policy, Politics, and Gender: Women Gaining Ground. West Hartford, CT: Kumarian Press.

Stienstra, Deborah. 1994. Women's Movements and International Organizations. New York: St. Martin's Press.

Stromquist, Nelly P. 1994. Gender and Basic Education in International Development Cooperation. UNICEF Staff Working Papers no. 3.

Thomas, George M., John W. Meyer, Franciso O. Ramirez, and John Boli. 1987. Institutional Structure: Constituting State, Society and the Individual. Newbury Park, CA: Sage.

Tinker, Irene. 1990. Persistent Inequalities: Women and World Development. New York: Oxford University Press.

Toubia, Nahid. 1993. Female Genital Mutilation: A Call for Global Action. New York: Women, INK.

_. 1995. "Female Genital Mutilation." Pp. 224-37 in Women's Rights, Human Rights, edited by J. Peters and A. Wolper. New York: Routledge.

UN (United Nations). 1946-95. United Nations Yearbooks. New York: UN.

- 1975. Declaration of Mexico on the Equality of Women and Their Contribution to Development and Peace. New York: UN.

1985a. The Nairobi Forward-looking Strategies for the Advancement of Women. New York: UN. 
1985b. Report of the World Conference to Review and Appraise the Achievements of the United Nations Decade for Women: Equality, Development, and Peace. New York: UN.

- 1986. Report of the Working Group on Traditional Practices Affecting the Health of Women and Children. E/CH.41986/42. New York: UN.

-1987. Report on the Regional Seminar on Traditional Practices Affecting the Health of Women and Children in Africa. Addis Ababa, Ethiopia.

1995. The World's Women. New York: UN.

1996. The United Nations and the Advancement of Women, 1945-1996. New York: UN.

UNDP (United Nations Development Programme). 1997. Human Development Report 1997. New York: Oxford University Press.

UNESCO. 1975. UNESCO and the International Decade for Women. Paris: UNESCO Press.

- 1986. "Meeting of the Multidisciplinary Panel on Continued Action to Give Effect to the Emphasis Set Out in the Medium Term Plan." ED.87/WS/4.

1992. Promotion of Primary Education for Girls and Disadvantaged Groups. Thailand: UNESCO Principal Regional Office for Asia and the Pacific.

1993. Educating Girls and Women in Africa. Paris: UNESCO Press.

-1994. Compiling Statistics on Education for Girls and Women. Paris: UNESCO Press.

1995a. Education of Girls and Women: Towards a Global Framework for Action. Paris: UNESCO Press.

- 1995b. Pre-Evaluation des activites relatives aux femmes dans les Programmes de l'UNESCO. Internal report. Paris: UNESCO.

UNESCO/UNICEF Programme of Educational Assistance. 1983. "Women's Education in a Rural Environment." Thailand: UNICEF/UNESCO Regional Office for Education in Asia and the Pacific.

Union of International Associations. 1945-98. Yearbook of International Organizations. Munich: K. G. Saur.

WHO (World Health Organization). 1996. Female Genital Mutilation: Information Kit. Geneva: WHO.

Winslow, Anne, ed. 1995. Women, Politics and the United Nations. Westport, CT: Greenwood Press.

$\rightarrow$ Young, Gay, Lucia Fort, and Mona Danner. 1994. "Moving from the 'Status of Women' to 'Gender Inequality': Conceptualisation, Social Indicators and an Empirical Application." International Sociology 9(1):55-85. 